\title{
Stop the violence and play hockey
}

$\mathrm{P}$ eople say you should write a book, and I would, but I can't remember," said Ron Duguay a former National Hockey League (NHL) player who underwent neurologic tests as a result of concerns about his memory. ${ }^{1}$ Hockey players who participate in the NHL and wish to publish their memoirs are well advised to keep a diary of life events. Sadly, a number of them will not remember their successes when the time comes to write their story.

As a relative newcomer to Canada and a new spectator to hockey, I was fascinated by the skill, grace, speed and physical fitness needed to play the game. Simultaneously, I was appalled by the disgraceful and uncivilized practice of fighting and causing intentional head trauma. The tragic story of Sidney Crosby's layoff due to concussions has not been sufficient for society to hang its head in shame and stop violent play immediately. ${ }^{2}$

What researchers from the Center for the Study of Traumatic Encephalopathy, Boston University School of Medicine have found in the brains of three prominent hockey players - Rick Martin, Reggie Fleming and Bob Probert ${ }^{3-5}$ — should be enough to sway minds to impose a ban on all forms of intentional head trauma, including fighting, along with severe deterrent penalties such as lengthy suspensions for breaches. In 2009, McKee and colleagues reviewed 48 cases of neuropathologically verified chronic traumatic encephalopathy (CTE) and documented the findings of CTE in one football player and two boxers. ${ }^{5}$ To date, they have analyzed the brains of 70 athletes, and over 50 have had pathological evidence of CTE (Robert A. Stern, Professor of Neurology and Neurosurgery, Boston University School of Medicine, Boston Mass.: personal communication, 2011). The simple message from the work done by McKee and colleagues is that the brain does not tolerate repeated hits. CTE has been described in boxers and others under various names such as dementia pugilistica, punch drunk syndrome and boxer's encephalopathy. CTE is associated with memory disturbances, behavioural and personality changes, Parkinsonism, and speech and gait abnormalities. Hockey has now been unceremoniously added to the list of sporting activities that result in CTE.

Head trauma in hockey has several causes, which include fighting and direct intentional hits to the head. The records of enforcers suggest that they fight a lot and get hit on the head a lot. Remembered by fans for his flowing locks of hair, Duguay was not a fighter. He played centre, almost always without a helmet, and admits being hit on the head several times. Luckily, the main intention in hockey is to score goals rather than to cause lasting brain damage in opponents - which seems to be the main intention in boxing.

Supporters of fighting argue that it has always been integral to hockey. This brutal tradition should be given up now that research has shown that repeated head trauma can cause severe progressive brain damage. Supporters might further argue that spectators expect fighting and that the game will become less enthralling without intentional head hits. However, it is difficult to predict the behaviour of people following legislation. For example, many had argued that banning smoking in bars and restaurants would result in reduced numbers of customers. This did not happen. Instead the rates of admission to hospital for heart attacks and lung diseases decreased. If fighting is banned, several spectators who currently do not watch the game may start watching it.

Scientists might argue that three sliced up brains is not enough evidence and that long-term cohort studies are needed to prove beyond doubt that hockey players are at risk of CTE. Evidence from boxing injuries collected over decades shows that repeated head trauma can cause brain damage. This evidence can be extrapolated to hockey. Vested interests will no doubt lobby to prevent a ban on fighting, but I call on all doctors to support a ban on all forms of intentional head trauma and endorse deterrent penalties in hockey.

Fifty-two concerned players have agreed to donate their brains to the brain bank in Boston (Robert A. Stern: personal communication, 2011). But how many brains should researchers have to slice up to convince NHL players that they are at risk of permanent and progressive brain damage? Should we not stop the violence now and get on with the main objective of hockey, which is scoring goals? Maybe the class action suit filed against the National Collegiate Athletic Association by a former student who played for the Panthers and has memory loss, depression and migraines, which he asserts he suffered as a result of concussions playing football, may provide the final impetus for change.

As I was writing this editorial, a fourth hockey player, enforcer Derek Boogaard, has been found to have CTE. ${ }^{7}$ At this rate, this editorial may never be up to date.

\section{Rajendra Kale MD}

Editor-in-Chief (Interim)

\section{References}

1. Schwarz A, Klein JZ. Brain damage found in hockey player [Re: Fleming and Dubuay quote]. New York Times 2009 Dec. 17. Available: www.nytimes.com/2009/12 /18/sports/hockey/18concussion.html?pagewanted=2\&_r=1 (accessed 2011 Nov. 25).

2. Sidney Crosby out again with concussion-like symptoms. Toronto $(\mathrm{ON})$ : CBC News; 2011. Available: www.cbc.ca/sports/hockey/nhl/story/2011/12/12-sp-nhl-crosby .html?com=rss (accessed 2011 Dec. 14).

3. Ex-NHL great Rick Martin had degenerative brain disease. Toronto $(\mathrm{ON})$ : CBC News; 2011. Available: www.cbc.ca/news/canada/story/2011/10/05/rick-martin-ctebrain-national.html (accessed 2011 Nov. 25).

4. Hayley Mick. Probert suffered from degenerative brain disease, scientists find Globe and Mail [Toronto] 2011 Mar. 16. Available: www.theglobeandmail.com /sports/hockey/concussions/nhler-bob-probert-suffered-from-degenerative-brain -disease-scientists-find/article1927734 (accessed 2011 Nov. 25).

5. McKee AC, Cantu RC, Nowinski CJ, et al. Chronic traumatic encephalopathy in athletes: progressive tauopathy after repetitive head injury. J Neuropathol Exp Neurol 2009;68:709-35.

6. Kondro W. Class action lawsuit filed on behalf of college athletes who suffered concussions. In: For the Record. CMAJ 2012;184:E9-10.

7. Branch J. Derek Boogaard: a brain 'going bad.' New York (NY): New York Times 2011 Dec. 5. Available: www.nytimes.com/2011/12/06/sports/hockey/derek-boogaard-abrain-going-bad.html?pagewanted=all (accessed 2011 Dec. 13).

Competing interests: See www.cmaj.ca/site/misc/cmaj_staff.xhtml.

Correspondence to: $C M A J$ editor, pubs@cmaj.ca

CMAJ 2012. DOI:10.1503/cmaj.112081 